ALTRUIS, e-ISSN 2620-5513, p-ISSN 2620-5505, Vol. 1, No. 1, April 2018

Abdimas Altruis: Jurnal Pengabdian Kepada Masyarakat

http://e-journal.usd.ac.id/index.php/ABDIMAS

Universitas Sanata Dharma, Yogyakarta

\title{
ANGGUR TUA DI LADANG LEMBEAN: Formasi Berkelanjutan dalam Kompetensi Naratif bagi Pelayanan Lansia
}

\author{
P. Mutiara Andalas \\ Program Studi Pendidikan Agama Katolik FKIP Universitas Sanata Dharma \\ mutiaraandalas@usd.ac.id \\ https://doi.org/10.24071/altruis.2018.010107
}

\begin{abstract}
The orphanage management see urgent needs to include 'narrative competence' in staff formation for the more holistic service of the elderly. The elderly psychosocial needs require the availability of staff or support groups to hear the story of elderly life. Limitations of staff at Bethania, Lembean, North Minahasa nursing home to meet these needs provide space for support groups to fill this role temporarily. In addition to applying narrative skills in communication with the elderly, this community service becomes a privileged opportunity for the researcher who is an informal teacher in this field to deepen the 'narrative competence' of the elderly. Holistic service to the elderly in the context of the demographic revolution requires the organization of nursing homes to immediately organize sustainable formation for staff in 'narrative competence'.
\end{abstract}

Kata Kunci: formasi berkelanjutan, ilmu lansia, kelompok pendukung, kompetensi naratif, lansia, pelayanan holistik

\section{PENDAHULUAN}

\section{Latar Belakang}

Tarekat Yesus Maria Yosef (YMY) secara resmi memulai pelayanan kepada lansia di panti wredha Bethania, Lembean, Minahasa Utara, berdasarkan surat keputusan No.01/ORSOS/MIN/1998. Pengabdian masyarakat disana berangkat dari analisis kebutuhan panti wredha akan keberadaan kelompok pendukung (supportive group) dalam pelayanan kepada lansia. Keterbatasan staf dihadapan beban kerja di lapangan menjadikan cita-cita pelayanan holistik terhadap lansia terbatas menjangkau pemenuhan kebutuhan hidup dan kesehatan dasar. Kebutuhan lansia akan staf dengan kompetensi sosial mendengarkan kisah hidup mereka belum terpenuhi. Berdasarkan pembicaraan dengan pengelola panti wredha Bethania, pengabdian masyarakat membantu staf dalam melayani lansia laki-laki. Pelayanan berlangsung dalam tiga shift dengan pembagian kerja 1 staf pada pagi, 1 staf pada siang, dan 2 staff pada malam.

\section{Wawasan dan Rencana Pemecahan Masalah}

'Revolusi demografis' menjadi kosakata baru yang lahir dari fenomena lansia dalam kurva kependudukan pada level global. Keluarga, profesional kesehatan, pengambil kebijakan kesehatan, dan bahkan pemerintah mencari strategi agar pertambahan harapan hidup pada lansia terbebas dari ancaman kemiskinan, sakit, disabilitas dan isolasi. Perhatian pada fenomena ini telah melahirkan kajian akademik 'gerontology', bahkan konsentrasi 'social gerontology' (Achenbaum, 1995) dan 'narrative gerontology' (Kenyon dkk, 2011; de Medeiros, 2014). Persoalannya, hasrat libidinal manusia untuk awet muda (youthfulness) menjadikannya ketakutan ketika ia memasuki usia lanjut (Minichiello \& Coulson, 2005: xi, xv). Pertanyaannya perlu bergeser menjadi 'positive ageing', pencarian strategi memasuki masa lanjut usia dengan segala kompleksitas secara bermakna (xv. $24-7)$.

Enam belas lansia laki-laki menjadi subyek pengabdian masyarakat pada 7 Mei - 7 Juni 2017. Sejarah kesehatan sebagai penyintas stroke, disabilitas, bahkan kelemahan mental menjadikan lansia menyesuaikan hidup dengan kondisi fisik sekarang. Beberapa masih mempertanyakan alasan kepindahan dari rumah asal ke panti wredha. Mereka memandang diri sebagai 'rongsokan' dan panti wredha sebagai 'rumah menanti ajal'. Beban kerja di panti wredha menghalangi staf untuk berempati lebih jauh dengan pergumulan kemanusiaan, bahkan iman lansia. Selain membantu staf melayani kebutuhan dasar lansia, terutama yang telah 
kehilangan kemandirian, saya menempatkan diri sebagai kelompok pendukung (supportive group) yang melengkapi peran yang staf memiliki keterbatasan untuk memenuhinya. Saya mengoptimalkan waktu bebas untuk mendengarkan narasi lansia berikut pergumulannya.

\section{Tujuan dan Manfaat Pengabdian}

Pengabdian masyarakat di panti wredha Bethania bertujuan untuk memfasilitasi pemenuhan kebutuhan psikososial lansia akan pendengar terhadap pergumulan hidup mereka. Keberadaan kelompok pendukung melengkapi pendampingan holistik terhadap lansia yang staf di panti wredha kesulitan untuk memenuhinya sendirian. Keberadaan kelompok pendukung selama waktu shift kerja memudahkan lansia yang hendak mengisahkan narasi hidup tanpa harus mengurangi kualitas waktu staf dalam melayani kebutuhan dasar mereka di panti wredha. Sebaliknya, kebelumterpenuhan, apalagi ketidakterpenuhan pelayanan psikosial dapat meresikokan lansia terutama terhadap bahaya isolasi sebagaimana para pakar lansia telah menengarainya sebagai salah satu ancaman utama terhadap kehidupan lansia dalam konteks baru revolusi demografis pada level global.

Selain memberikan manfaat langsung kepada lansia yang tinggal di panti wredha Bethania, pengabdian masyarakat ini membawa kebermanfaatan kepada semua pihak yang terlibat dalam pelayanan kepada lansia dan mendalami kandungan kosakata 'kompetensi naratif.' Para pakar ilmu gerontology telah melihat 'kompetensi naratif' penting dan mendesak bagi staf yang memberikan pelayanan kepada kehidupan harian lansia. Kajian akademik tentang 'kompetensi naratif' berangkat dari perspektif lansia konteks Indonesia terbilang rintisan. Narasi memiliki tempat sentral dalam kehidupan lansia. Penemuan lansia sebagai narator harapannya bermanfaat dalam memperkaya pemahaman akan narasi yang masih menyisakan ruang lapang pengayaan dalam teologi kisah (narrative theology) yang pelaksana pengabdian masyarakat mengembangkannya.

\section{Kajian Teoretik}

Kelompok pendukung (supportive group) memiliki beberapa tujuan utama berikut dalam memfasilitasi transformasi staf yang merawat kesehatan lansia. Pertama, kelompok pendukung dapat memberikan ruang dan waktu sehingga staf memahami pengalaman emotif bekerja dalam institusi, secara khusus pengalaman kontak dekat dengan pasien lansia yang lemah. Kedua, mendorong staf untuk memikirkan perasaan pasien mereka tentang berada dalam perawatan jangka panjang, menunjukkan kepada staf bahwa sebagian dari perasaan mereka sendiri mungkin merupakan komunikasi tak sadar dari pasien mereka. Ketiga, membantu staf memahami perasaan mereka tentang perkembangan dan perubahan dalam institusi barangkali mempengaruhi kerja. Keempat, memikirkan hubungan antara staf, kelompok pendukung, dan institusi secara keseluruhan (Terry, 1997: 133).

Tenaga perawat kesehatan profesional membangun 'kompetensi naratif' dan mempraktekkannya dalam aktivitas harian. Perawatan kesehatan, pada dasarnya, emansipatoris,

yaitu, memberdayakan orang lain untuk memahami pengalamandalam situasi tertentu dan untuk mengekspresikan diri, untuk menceritakan kisah mereka. Ini berakar pada rasa solidaritas. Perawat kesehatan dan subyek yang menerima "hidup berdampingan." Perawat kesehatanbarangkali memiliki pengetahuan khusus yang sangat membantu dalam situasi tertentu pada waktu tertentu, namun hal ini tidak menjadikannya pakar atas kehidupansecara umum atau, lebih penting lagi, seorang pakar atas kehidupan orang lain. Perawat kesehatan dan subyek yang menerima perawatan keduanya mitra penulis dalam perjumpaan biografis (Randall \& Kenyon, 2002; Kenyon dkk. 2011: 371).

Kita mendeteksi kandungan puisi, bahkan sastra dalam kehidupan lansia (poetics of aging). Manusia pertama-tama dan terutama adalah pemakna kehidupan. Sarana utamanya narasi. Kehidupan manusia lebih dari sekedar rakitan fakta telanjang atau peristiwa mentah. Kehidupan manusia merupakan sebuah kisah. Kehidupan manusia secara esensial adalah sebuah teks. Seiring manusia memasuki usia lanjut (getting old), berkembang dalam usia lansia (growing old), teks itu semakin panjang dan berisi. Ia berjalinan dengan [kon]teks-[kon]teks lain. Lansia merupakan 'karya sastra yang hidup' (living works of literature). Mereka karya sastra yang sedang mengabjad (narratives-in-the-making). Mereka sekaligus penulis kisah dan pengisah, karakter dan pembaca. Untuk membaca kisah hidup dan kemudian mengisahkannya kepada orang lain, lansia perlu 'literary self-literacy' (Randall \& McKim, 2008: 5-6).

\section{METODE}

Metode pengabdian masyarakat di Panti Wredha Bethania observasi partisipatif. Alokasi waktu pengabdian masyarakat memperhitungkan aktivitas lansia dan beban kerja staf yang shift dalam melayani kebutuhan mereka. Jadual harian mulai dengan ibadat pagi (05.30 - 06.00 WIT), sarapan pagi (06.00 - 07.00 WIT), kegiatan di dalam rumah sampai istirahat siang (09.30 - 13.00 WIT), dan kegiatan setelah istirahat siang 
sampai makan malam (15.30 - 19.00 WIT). Kegiatan ibadat dan sarapan pagi bertukar pada hari Minggu. Saya membantu staf mengambil makanan dan minuman di dapur, menyuapi lansia yang kehilangan kemandirian, mencuci peralatan makan dan minum untuk kemudian mengembalikannya ke dapur, membersihkan ruang aktivitas mereka, dan melayani mereka keluar dan masuk tempat tidur. Pada saat lansia rekreasi, saya duduk diantara mereka untuk mendengarkan kisah kehidupan, bahkan narasi iman.

\section{HASIL DAN PEMBAHASAN}

Definisi konvensional tentang lansia perlu pengkajian ulang dihadapan konteks baru pertambahan harapan kehidupan. Sebelumnya masyarakat menghimpitkan lansia dengan kematian. Jarak antara masa lansia dan kematian dekat sekali. Panti wredha menjadi perhentian terakhir lansia sebelum kematian. Hidup sebagai lansia di panti wredha identik dengan kesendirian, komplikasi penyakit, bahkan sakratul maut. Revolusi demografis berangsur mentransformasikan paras panti wredha berikut pelayanan kepada lansia. Sekarang, masa lansia berlangsung lebih panjang daripada sebelumnya. Demikian pula masa tinggal lansia di panti wredha. Penghuni datang ke panti wredha pada usia lansia dalam keadaan sehat walafiat. Selain kesendirian, penyakit, dan kematian, panti wedha juga menjadi lokasi kita mendengarkan tuturan lansia tentang persahabatan, kebahagiaan bahkan kehidupan.

Selain melaksanakan kegiatan-kegiatan harian rutin seperti makan dan minum, membersihkan diri dan lingkungan, menjaga kesehatan dibawah bimbingan staf, dan rekreasi, mereka juga memiliki waktu untuk berbicara satu dengan yang lain. Komunikasi antarlansia intensif terutama berlangsung diantara mereka yang telah tinggal bersama selama beberapa waktu. Persahabatan memampukan lansia untuk menangkap pesan rekan bicara meskipun tuturan yang menyandang keterbatasan. Pada saat bersamaan, komunikasi dengan lansia lain juga menyandang keterbatasan. Keterbatasan tuturan menyulitkan lansia lain dalam menangkap kandungan pesan percakapan. Sebagian mengalami keputusasaan dalam menangkap kandungan pesan dalam tutur, apalagi gesture. Apalagi, komunikasi sebagian lebih dengan gesture daripada tutur. Panti wredha merupakan lokasi narasi. Lebih lanjut, lansia merupakan habitat narasi.

Masa live-in sebulan merupakan undangan dalam membangun persahabatan dengan lansia di panti wredha Bethania. Tawaran persahabatan datang pertama kali dari lansia. Mereka terbuka terhadap kehadiran saya sebagai orang baru di tengah-tengah mereka. Mengetahui bahwa saya hidup berdampingan dengan mereka sebagai pendukung staf, lansia menuturkan halaman-halaman kehidupan kepada saya. Kehidupan lansia gambarannya sebuah novel, sekurang-kurangnya novelette. Gesture adalah bahasa narasi yang saya belajar banyak dari lansia. Awalnya saya terbata-bata dalam menangkap kata-kata dalam gesture mereka. Bahkan, saya tidak dapat menangkap sama sekali kandungan tutur dalam gesture. Mereka memiliki kesabaran dalam memperkenalkan alfabet-alfabet dan tanda-tanda baca dalam bahasa gesture. Ia bahasa yang valid bagi lansia untuk menuturkan pengalaman hidupnya.

Lokasi pemakaian bahasa baik tutur maupun gesture di panti wredha istimewa. Ruangan sekeliling panti wredha ketika lansia menyantap sarapan dan makan siang bersama menjadi lokasi mereka saling komunikasi intensif. Lansia yang masih memiliki mobilitas fisik lebih banyak pilihan lokasi komunikasi. Sebagian lansia lebih terbatas dalam pilihan lokasi komunikasi, bahkan bergantung pada staf yang meletakkan kursi roda mereka. Teras rumah, ruangan utama didepan televisi, dan sudutsudut ruangan yang menyediakan kursi di dalam panti wredha merupakan lokasi-lokasi favorit lansia dalam menjalin komunikasi satu sama lain pada saat-saat luang. Sebagian lansia yang memiliki keterbatasan dalam mobilitas tinggal memiliki tempat tidur sebagai lokasi untuk berkomunikasi dengan lansia lain, staf, dan kelompok pendukung. Kapel lokasi bagi lansia untuk menjalin komunikasi dengan dunia lebih luas.

Selain lokasi, waktu komunikasi bahasa tutur dan gesture lansia memiliki keistimewaan. Komunikasi lansia di panti wredha lebih pendek durasinya dalam sehari. Kehidupan lansia, terutama yang memiliki keterbatasan fisik lebih berat, berakhir lebih dini. Bahkan, santap malam beberapa lansia sudah berlangsung di atas tempat tidur. Waktu-waktu tunggu setelah aktivitas bersama terasa lama, bahkan monoton, sebelum staf atau kelompok pendukung mendorong kursi roda mereka ke kamar tidur. Permintaan berulang sebagian lansia kepada staf untuk segera mendorong kursi roda mereka ke kamar tidur sebelum waktunya kemungkinan mengungkapkan kelelahan melalui kehidupan dengan rutinitas monoton dalam kesendirian. Selain terbuka untuk menjadi pendengar bagi lansia pada waktu-waktu luang, waktu-waktu lain masih sangat terbuka untuk komunikasi ketika kita memiliki kedekatan dengan mereka.

Revolusi demografis mewajibkan semua pihak yang terlibat dalam perawatan kesehatan untuk mengubah gambaran konvensional akan lansia dari beban menjadi berkah. Perubahan serupa perlu berlangsung diantara mereka dalam memandang ulang panti wredha. Meskipun istilah revolusi demografis barangkali masih asing disana, berangsur muncul kesadaran terhadapnya dan kebutuhan bagi staf, termasuk kelompok pendukung, 
untuk memiliki 'kompetensi naratif.' Panti wredha Bethania menjadi sekolah kisah bagi saya sebagai pemula dalam teologi narasi. Lansia menjadi pendidik di sekolah narasi. Syarat tunggalnya pembelajar di sekolah narasi ini adalah kesediaan untuk 'hidup berdampingan' dengan lansia. Ruang kelas narasi adalah kehidupan sehari-hari lansia. Panti wredha menjadi lokasi baik bagi staf maupun kelompok pendukung dalam mengembangkan 'kompetensi naratif.'

Keruntutan, apalagi kefasihan, mengeriput dalam narasi lansia. Tuturan mereka semakin terbata-bata dalam kata-kata lirih yang seringkali urung selesai pada akhir. Tuturan mereka merupakan kata-kata yang keheningan panjang mengapitnya. Jeda menjadi penghubung antarkata. Jawaban mereka atas pertanyaan kita beringsut menjadi "ya" atau "tidak". Narasi baru yang mereka tuturkan kepada kita seringkali merupakan ulangan terhadap kisah sebelumnya dengan kelengkapan tanda baca yang terletak pada tempat yang sama. Kefasihan narasi lansia bergeser dari tutur ke gesture. Keruntutan mereka bergeser dari grammar kepada semantics. Alih-alih memandang lansia mengalami kemunduran dalam grammar dan kekaburan dalam semantics, saya melihat grammar lansia kembali dalam bentuk paling dasar, sementara semantics memasuki kedalaman.

Saya mencari metafor Kitab Suci untuk menggambarkan pandangan baru masa lansia alihalih'getting old', 'growing old.' Saya mengeksplorasi kosakata biblis untuk menggambarkan masa lansia baik sebagai 'lengthening' maupun 'thickening' dari 'living works of literature.' "Sebab setiap pohon dikenal pada buahnya. Karena dari semak duri orang tidak memetik buah ara dan dari duri-duri tidak memetik buah anggur" (Luk 6, 44). Dalam perikop mukjizat perkawinan di Kana, di tengah-tengah situasi darurat tuan rumah yang kekurangan anggur, Yesus mengubah air dalam tempayan menjadi anggur. Tamu takjub dengan kualitas anggur yang mereka cecap. "Setiap orang menghidangkan anggur yang baik dahulu dan sesudah orang puas minum, barulah yang kurang baik; akan tetapi engkau menyimpan anggur yang baik sampai sekarang" (Yoh 2, 10). Lansia di panti wredha Bethania adalah anggur tua, masak, di ladang.

\section{KESIMPULAN DAN SARAN}

Formasi staf yang berkelanjutan merupakan kebutuhan baru yang semakin mendesak realisasinya untuk pengelolaan lebih lanjut Panti Wredha Bethania dalam melayani lansia yang menjalani kehidupan didalamnya. Inklusi program 'kompetensi naratif' bagi staf menjadikan perawatan kesehatan lansia menjadi semakin holistik. Program ini harapannya memampukan staf untuk 'hidup berdampingan' dengan lansia. Ia mampu menjadi pendengar bagi lansia yang memerlukannya sewaktu-waktu. Lebih lanjut, staf solider terhadap lansia yang datang ke panti dengan membawa masalah atau mengalami masalah ketika hidup di lokasi baru. Pada kenyataannya, beberapa pasien membutuhkan telinga staf sekurang-kurangnya pada waktu-waktu tertentu. Untuk kebutuhan sepenting ini, Panti Wredha Bethania akan sangat bijak jika mengurangi ketergantungan pada kelompok pendukung yang tinggal disana secara temporer.

\section{DAFTAR PUSTAKA}

Achenbaum, W. Andrew. 1995. Crossing Frontiers: Gerontology Emerges as a Science. New York, NY: Cambridge University Press.

Backhaus, Peter. Ed. 2011. Communication in Elderly Care: Cross-Cultural Perspectives. New York, NY: Continuum.

Blackburn, James A. \& Catherine N. Dulmus. 2007. Handbook of Gerontology: Evidence-Based Approaches to Theory, Practice, and Policy. New Jersey, NJ: John Wiley \& Sons, Inc.

Hermalin, Albert. Ed. 2002. The Well-being of the Elderly in Asia: A Four-Country Comparative Study. Michigan, MI: The University of Michigan Press.

Hooyman, Nancy R., Kevin Y. Kawamoto \& H. Asuman Kiyak. 2015. Aging Matters: An Introduction to Social Gerontology. New York, NY: Pearson.

Dannefer, Dale \& Chris Phillipson. Eds. 2010. The Sage Handbook of Social Gerontology. Thousand Oaks, CA: Sage.

Kenyon, Gary, Ernst Bohlmeijer \& William L. Randall. 2011. Storying Later Life: Issues, Investigations, and Interventions in Narrative Gerontology.

Minichiello, Victor \& I. Coulson. Eds. 2005. Contemporary Issues in Gerontology: Promoting Positive Ageing. New South Wales, AUS: Allen \& Unwin.

Phillips, Judith, Kristine Ajrouch \& Sarah HillcoatNallaetamby. 2010. Key Concepts in Social Gerontology. Thousand Oaks, CA: Sage.

Randall , W. , \& Kenyon , G. 2002. "Reminiscence as reading our lives: Toward a Wisdom Environment" in J. Webster \& B. Haight (Eds.), Critical advancesin reminiscence: Theoretical, empirical, and clinical perspectives (pp. $233-$ 253 ). New York : Springer.

Randall , W. , \& McKim , A. 2008. Reading Our Lives: The Poetics of Growing Old. New York : Oxford University Press.

Rowles, Graham D., \& Nancy E. Schoenberg. Eds. 2002. Qualitative Gerontology. Second Edition. New York, NY: Springer Publishing Company.

Samanta, Tannistha. Ed. 2017. Cross-Cultural and Cross-Disciplinary Perspectives in Social Gerontology. New York, NY: Springer Publishing Company. 
Sheets, Debra J., Dana Burr Bradley \& Jon Hendricks. Eds. 2000. Enduring Questions in Gerontology. New York, NY: Springer Publishing Company.

Stuart-Hamilton, Ian. Ed. 2011. An Introduction to Gerontology. New York, NY: Cambridge University Press.

Terry, Paul. 1997. Counseling the Elderly and their Carers. Foreword by Ellen Noonan. London, UK: Macmillan Press.
Weicht, Bernhard. 2015. The Meaning of Care: The Social Construction of Care for Elderly People. New York, NY: Palgrave Macmillan.

Wilmoth, Janet M. \& Kenneth F. Ferraro. Eds. 2007. Gerontology: Perspectives and Issues. Third Edition. New York, NY: Springer Publishing Company 